\title{
Konseling realitas untuk mereduksi stres pada orangtua tunggal
}

\author{
$\boldsymbol{\Psi}_{\text {PROCEDIA }}$ \\ Studi Kasus dan Intervensi Psikologi \\ p-ISSN 2302-1462; e-ISSN 2722-7669 \\ ejournal.umm.ac.id/index.php/procedia \\ 2021, Vol 9(4):152-157 \\ DOI:10.22219/procedia.v9i4.16349 \\ (c) The Author(s) 2021 \\ (ㅇ)()ㅇㅇ 4.0 International license
}

\author{
Hanif Kartika Indrasari ${ }^{1}$
}

\begin{abstract}
The client is a 57 years old woman with complaints of feeling disappointed, irritable, palpitations, chest pain, sweating for no reason that interferes with daily activities. The results of the medical examination did not show any physiological problems. Based on the assessments carried out through interviews, observation, graphic tests, Depression Anxiety Stress Scale (DASS) and WHODAS indicate that the client is experiencing stress. The intervention provided was six sessions of reality counseling. The results of the intervention showed a decrease in stress scores from 25 to 13 on the DASS scale and accompanied by changes in more productive behavior.
\end{abstract}

\section{Keywords}

Behavior changes, reality counseling, stress

\section{Pendahuluan}

Stres secara ilmiah diartikan sebagai suatu keadaan dimana seseorang mengalami kesulitan, tekanan, beban, atau kesengsaraan. Stres dapat disebabkan karena adanya tekanan dari lingkungan. Selain itu stress juga merupakan suatu reaksi fisiologis karena adanya tekanan secara psikologis. Lazarus dan Folkman berpendapat bahwa stres dialami oleh individu ketika dirinya merasa bahwa beban yang dirasakannya melebihi kemampuan yang dimilikinya. Hal ini menunjukkan adanya faktor appraisal (penilaian) yang mempengaruhi stress pada individu. Appraisal (penilaian) adalah suatu penilaian diri terhadap permasalahan yang sedang dialami. Lazarus dan Folkman membagi proses penilaian menjadi dua yang terjadi ketika seseorang sedang mengalami stres yaitu penilaian primer dan penilaian sekunder. Penilain primer merupakan suatu keadaan yang dilakukan oleh seseorang saat mendapatkan suatu peristiwa dalam hidupnya dan mengevaluasi pengaruh yang akan muncul dalam dirinya. Sedangkan penilaian sekunder adalah cara seseorang dalam menentukan koping saat berada pada kondisi atau situasi yang mengancam. Koping tergantung dengan penilaian seseorang terhadap situasi tertentu (Lazarus \& Folkman, 1984).

Stres juga didefinisikan sebagai persepsi seseorang terhadap suatu kondisi psikologis dan faktor lain yang membuat seseorang merasa tidak mampu menghadapinya. Lazarus juga berpendapat bahwa stres dapat menimbulkan perasaan terancam dan berkurangnya kemampuan individu dalam menghadapi masalah. Pendekatan mengenai stres sebagai stimulus yaitu berfokus pada lingkungan dan respon yang fokus pada reaksi individu (Hubbs et al., 2012).
Stres merupakan interaksi antara stresor yang direalisasikan dalam bentuk tingkah laku melalui aspek kognitif dan emosional. Stres merupakan hal yang lebih kompleks bukan hanya sebuah interaksi antara stimulus dan respon. Stres dapat menimbulkan berbagai reaksi respon mulai dari reaksi kognitif, fisiologis dan emosional. Reaksi kognitif dari stress adalah kesulitan konsentrasi dan aktivitas kognitif lainnya. Respon fisiologis stres yaitu pada metabolisme tubuh yang cenderung akan meningkat seperti tekanan jantung dan darah. Sedangkan respon emosional yaitu munculnya emosi negatif seperti rasa kecemasan hingga depresi (Lazarus \& Folkman, 1984).

Stres sebagai bentuk dari rasa tidak mampu seseorang dalam menghadapi tekanan yang berdampak pada fisik dan psikologis (Keyes \& Haidt, 2016). Stres secara behavioral yaitu munculnya perilaku negatif seseorang ketika mendapatkan tekanan, kemampuan untuk mengatasi masalah tersebut, dan coping strategi pada setiap individu. Strategi koping memberikan peran penting dalam perkembangan emosional seseorang (Lopez, 2009). Stres merupakan suatu reaksi fisik yang sifatnya adaptif terhadap stresor dari dalam maupun dari luar diri yang menyebabkan adanya perubahan fisik maupun psikologis (Tan et al., 2012).

Stres juga dapat diartikan sebagai suatu keadaan dimana individu tidak mampu memenuhi apa yang diinginkan. Harga diri adalah bagaimana individu memiliki

${ }^{1}$ Universitas Muhammadiyah Malang,Indonesia

Korespondensi:

Hanif Kartika Indrasari, Direktorat Program Pascasarjana, Universitas Muhammadiyah Malang, Jl. Tlogomas 246 Malang, Indonesia Email: kartikahanif@yahoo.com 
kualitas diri sehingga mampu menghargai dirinya sendiri. Oleh karena itu, dapat dikatakan bahwa individu yang mengalami stres adalah salah satu akibat dari rendahnya harga diri. Dalam hal ini orang dengan harga diri rendah cenderung akan lebih cepat bereaksi terhadap suatu stresor atau tekanan (Galanakis et al., 2016).

Penelitian yang dilakukan oleh Vahidiborji et al. (2017) menunjukkan terapi realitas mampu menurunkan kecemasan, depresi dan stres yang terjadi pada remaja putri. Penerapannya terapi realitas dapat meningkatkan penyesuaian seseorang pada stres dan kecemasan yang mereka rasakan. Remaja dalam penelitian ini diajarkan untuk bertanggung jawab terhadap apa yang mereka lakukan sehingga secara emosional mereka lebih dapat menyesuaikan diri ketika ada kondisi yang tidak mereka harapkan terjadi.

Menurut Sommers-Flanagan \& Sommers-Flanagan (2009) terapi realitas digunakan untuk membantu memenuhi lima dasar kebutuhan manusia yang dibutuhkan keluarga dengan pasien skizofrenia agar tidak menjadi beban berat bagi mereka. Kelima kebutuhan dasar tersebut antara lain kebutuhan untuk kelangsungan hidup, cinta dan rasa memiliki, kekuatan atau prestasi, serta kebebasan dan kebahagiaan. Dalam beberapa kasus, terapi realitas dapat digunakan pada berbagai usia dan demografi lainnya. Konsep teori dari terapi ini adalah melibatkan pengambilan tanggung jawab dan konsekuensi atas pilihan dari diri mereka sendiri (Ellsworth, 2007; Nematzadeh \& Sary, 2014; Yao et al., 2017).

Terapi realitas merupakan terapi yang berfokus pada tingkah laku saat ini. Terapis berfungsi sebagai model desngan mengajarkan metode yang dapat membantu subjek menghadapi kenyataan hidup dan pemenuhan kebutuhan dasar tanpa merugikan diri sendiri maupun orang lain. Fokus utama terapi ini adalah agar individu mau menerima tanggung jawab sehingga kondisi mental menjadi lebih baik. Tujuannya adalah untuk memenuhi kebutuhan secara psikologis yang akan muncul seumur hidup (Corey, 2013). Terapi realitas melibatkan cara belajar dalam perencanaan sehingga dapat mengubah perilaku dengan lebih efektif.

Terapi realitas merupakan salah satu metode berdasarkan pemikiran realistis serta emosional. Teori ini berdasarkan pada perubahan perilaku ketika berhadapan pada kondisi yang tidak diinginkan. Selain itu juga dapat merubah aspek psikologis dari individu yang dapat berdampak pada berbagai aspek mental, psikologis, dan kepribadian seseorang (Glasser, 2003).

Terapi realitas dalam konseling membantu seseorang dalam memenuhi keinginan dan kebutuhan, dan mengevaluasi kebutuhan mereka menjadi suatu perilaku (Wubbolding, 2017). Masing-masing individu mengembangkan diri dan terlibat dengan orang lain sesuai dengan perannya untuk pembentukan identitas diri (Corey, 2013). Tujuan dari terapi realitas yaitu membantu individu mencapai rasa kebebasan dan tujuan yang mereka pikirkan sebagai penentu keberhasilan terapi. Dalam perjalanannya terapi realitas memiliki sasaran tidak hanya pada aspek kognitif dan perilaku saja, tetapi pengalaman masing-masing individu. Terapis harus mengetahui nilai, keterampilan, dan pengetahuan terkait terapi ini (Karimyar \& Mosallanejad, 2014).

Seseorang yang mampu mengatasi masalahnya dapat dikatakan bahwa dirinya dapat memberikan tujuan, makna, dan arah untuk dirinya maupun bagi lingkungannya (Call \& Mortimer, 2003). Terapi realitas membantu individu dalam merubah pikiran negatif mereka menjadi pemikiran yang positif sehingga individu mampu memenuhi kebutuhan dasar mereka untuk mencapai kestabilan emosi dan psikologis. Hal tersebut terkait dengan penyesuaian individu dalam menghadapi suatu permasalahan (Elsayed, 2017). Terapi realitas membantu individu menetapkan dan memperjelas tujuan-tujuan mereka. Terapis harus memiliki tujuan tertentu bagi subjek dalam pikirannya dengan menekankan bahwa kriteria psikoterapi yang berhasil sangat bergantung pada tujuan yang ditentukan oleh subjek (Nematzadeh \& Sary, 2014).

Pendekatan pada konseling realitas dapat membantu individu dalam mengidentifikasi keinginan, harapan, kebutuhan, mampu mengevaluasi diri dan menemukan alternatif pilihan realitas guna mengatasi permasalahan (Wubbolding, 2017). Terapis berfungsi sebagai guru dan model serta mengkonfrontasi subjek dengan cara-cara yang bisa membantu subjek menghadapi kenyataan dan memenuhi kebutuhan-kebutuhan dasar tanpa merugikan dirinya sendiri ataupun orang lain (Corey, 2013). Melalui konseling realitas, diharapkan subjek dapat mampu menyadari realita yang ada, kemampuannya untuk mengatasi masalah, mampu merasa setara dengan orang lain, menyadari kelebihan dan kekurangannya sehingga dapat memiliki konsep diri yang positif.

\section{Metode Asesmen}

Asesmen untuk penegakan diagnosa yang tepat dilakukan melalui serangkaian metode antara lain wawancara, observasi, tes grafis, skala stress pada Depression Anxiety Stress Scale (DASS) dan World Health Organization Disability Assessment Schedule (WHODAS). Wawancara klinis digunakan untuk mengetahui riwayat kondisi subjek dari awal hingga akhir dan dalam rangka mengurangi penderitaannya. Observasi digunakan untuk mengetahui bagaimana kondisi dan perilaku subjek selama asesmen dan intervensi. Sedangkan tes grafis digunakan untuk mengungkap kepribadian, konsep diri, hubungan dan pandangan Subjek terhadap lingkungan sekitarnya. Tes grafis yang diberikan adalah Draw a Person (DAP), BAUM.

Skala stress pada Depression Anxiety Stress Scale (DASS) digunakan untuk mengungkap tingkat stress pada subjek dalam pretest dan posttest dalam intervensi yang dilakukan. Serta WHODAS untuk mengetahui taraf keberfungsian subjek dalam pemahaman dan komunikasi dengan orang lain, penguasaan lingkungan, perawatan diri, 
partisipasi dalam lingkungan sosial, kehidupan sehari-hari dan masyarakat.

\section{Presentasi Kasus}

Subjek merupakan seorang wanita berusia 57 tahun berstatus janda. Subjek bekerja sebagai pembantu rumah tangga dan mempunyai satu anak laki-laki yang sudah berumah tangga. Saat ini subjek tinggal bersama anak, menantu dan dua orang cucu. Subjek merasa marah kepada menantunya terkait hutang piutang dan dugaan mencuri perhiasan miliknya sementara keluarga subjek termasuk orang yang takut untuk berhutang. Sejak saat itu subjek menjadi mudah marah dan kecewa pada menantunya.

Tiga hari kemudian, pada tanggal 8 september 2019 suami subjek meninggal karena sakit paru-paru yang sudah dideritanya selama tujuh tahun. Subjek merasa sedih namun sudah mengikhlaskan kepergian suaminya karena sudah lama sakit. Dua minggu setelah kematian suaminya, subjek kembali bekerja.

Sejak mengetahui menantunya berhutang, subjek menjadi mudah marah, kehilangan nafsu makan, sulit tidur dan sering melamun. Subjek juga kehilangan minat dalam melakukan sesuatu. Subjek banyak memikirkan dan mengkhawatirkan bagaimana dengan keuangan rumah tangga anaknya. Subjek mengkhawatirkan bagaimana beban anaknya yang sebagai pegawai honorer yang harus melunasi hutang istrinya sebanyak 50 juta. Subjek juga mengkhawatirkan bagaimana caranya untuk melunasi hutang-hutang tersebut dan bagaimana cara menghadapi menantu subjek. Keluhan fisik yang dirasakan subjek adalah merasa sering sakit kepala, merasakan kaku pada bagian leher, lemas dan tidak mempunyai tenaga. Subjek merasa kesulitan untuk tidur dan sering terbangun di malam hari yang dirasakan setiap hari.

Berdasarkan hasil tes, subjek merupakan individu yang kekanak-kanak dan memiliki kecenderungan hambatan sosial. Kematangan emosi subjek belum berkembang dengan baik dimana adanya keinginan untuk kembali kemasa kanak-kanak. Sifat subjek yang kekanak-kanakan cenderung membuat subjek ingin diperhatikan namun cenderung menolak untuk memperhatikan lingkungan dan menolak keadaan yang tidak menyenangkan. Subjek termasuk orang yang ragu-ragu, mudah takut dan frustasi sehingga subjek cenderung tidak mempunyai tujuan yang jelas. Subjek cenderung kurang dapat berpikir panjang dan analitis dikarenakan adanya hambatan berpikir sehingga membuat subjek cenderung cepat bereaksi atas hasil yang dicapainya. Berdasarkan hasil skala Depression Anxiety Stress Scale (DASS) didapatkan skor stres sebesar 25 dengan kategori sedang.

Intervensi yang akan diberikan kepada subjek yaitu konseling realitas. Reality therapy yang dicetuskan oleh William Glasser ini didasarkan pada teori yang menekankan bahwa manusia merupakan makhluk sosial dan setiap perilaku yang dikerjakan ada tujuannya. Oleh karena itu, manusia tergantung dari perilaku mereka sendiri dan bukan karena keluarga mereka, lingkungan mereka atau konflik saat usia anak-anak. Sebaliknya perilaku dipandang sebagai pilihan, dimana reality therapy berusaha untuk menghindari pemaksaan dan hukuman serta mengajarkan tanggung jawab (Wubbolding, 2017).

\section{Diagnosis dan Prognosis}

Berdasarkan hasil asesmen yang telah dilakukan dapat ditegakan diagnosis bahwa subjek mengalami stres Secara umum, taraf keberfungsian subjek berdasarkan WHODAS masih dapat berfungsi dengan baik.

Terapis memperkirakan keberhasilan dalam intervensi ini adalah baik. Hal ini dapat dilihat dari permasalahan yang dialami subjek selama tiga bulan terakhir dan subjek memiliki orientasi dan kesadaran yang baik terhadap permasalahan yang dihadapinya. Selain itu subjek sangat kooperatif ketika intervensi berlangsung. Taraf keberfungsian subjek berada pada kategori ringan dan secara keseluruhan dapat berfungsi dengan baik, hal ini juga mempengaruhi tingkat keberhasilan dalam intervensi ini.

\section{Intervensi}

Rencana intervensi yang digunakan dalam penanganan kasus ini yakni menggunakan konseling realitas. Konseling realitas mengajarkan cara untuk mengatasi dan membantu individu mengambil kendali yang lebih efektif terhadap kehidupan mereka. Konselor mengakui bahwa subjek memilih perilaku mereka sendiri sebagai cara untuk mengatasi frustasi yang disebabkan oleh hubungan yang tidak memuaskan (Corey, 2013)(.

Konselor percaya bahwa masalah yang mendasari kebanyakan subjek merupakan hal yang sama yaitu mereka terlibat dalam hubungan yang tidak memuaskan saat ini atau kurang memiliki hubungan atau tidak sama sekali dengan orang lain. Banyak masalah subjek disebabkan oleh ketidakmampuan mereka untuk terhubung, untuk menjadi dekat dengan orang lain, atau untuk memiliki hubungan yang memuaskan atau sukses dengan setidaknya satu orang yang penting dalam hidup mereka. Konselor membimbing subjek menuju hubungan yang memuaskan dan mengajarkan mereka cara berperilaku yang lebih efektif. Semakin banyak subjek dapat terhubung dengan orang, semakin besar peluang mereka untuk mengalami kebahagiaan (Corey, 2013).

Tujuan konseling realitas untuk membantu subjek dalam meningkatkan kualitas hidup dengan memahami perilaku, meningkatkan perilaku, membuat pilihan, mengidentifikasi dan memenuhi kebutuhan dasar. Dalam hal ini subjek pun bukan hanya mengatasi masalah yang dialaminya saat ini tetapi mencegah atau mengatasi masalah-masalah yang akan datang (Nelson-Jones, 2015).

Sesi I: Pengenalan terapi dan kontrak kerja. Pada sesi ini terapis menjalin rapport dan memperkenalkan program konseling yang akan dilakukan serta membuat 
kesepakatan yang harus ditepati selama intervensi. Konselor menjelaskan struktur pelaksanaan konseling yang akan dilakukan, mulai dari menjelaskan maksud dan tujuan konseling, asas-asas dalam konseling, serta peran konselor dan subjek dalam konseling yang akan dilakukan. Dilanjutkan dengan pemberian skala DASS sebagai pretest.

Pada sesi ini subjek dapat memahami maksud dan tujuan dari konseling yang akan dilakukan. Subjek bersedia mengikuti konseling dan berharap dapat mengatasi permasalahannya. Hasil skor skala DASS adalah 25 dengan kategori sedang.

Sesi II: : eksplorasi keinginan, kebutuhan dan persepsi (wants). Pada sesi ini, konselor membantu subjek dalam menemukan keinginan dan harapan subjek, menentukan apa yang subjek inginkan dari proses konseling dan dari lingkungan sekitarnya. Pada sesi ini, konselor mengarahkan subjek untuk mengungkapkan segala permasalahan yang dirasakannya. Sebelum memulai proses konseling, konselor memulai pembicaraan yang bersifat netral. Konselor menanyakan kabar dan kegiatan subjek hari ini. Kemudian konselor menjelaskan maksud dan tujuan dari konseling, asas dalam konseling dan peran masing-masing dengan tujuan agar subjek bisa terbuka dalam mengungkapkan masalahnya. Kemudian konselor mengarahkan subjek untuk mengungkapkan apa yang diinginkan dan dibutuhkan dalam hidupnya saat ini, baik yang berkaitan dengan dirinya, keluarga, dan teman.

Sesi III: Mendiskusikan perilaku total (doing). Pada sesi ini, subjek dan konselor mendiskusikan perilaku subjek, bagaimana pikiran, perasaan dan respon fisik ketika adanya perilaku yang tidak subjek sukai dari orang lain. Konselor membantu subjek membuat banyak pilihan untuk memenuhi keinginan dan kebutuhannya. Konselor mulai menanyakan mengenai tindakan apa yang subjek lakukan untuk memenuhi keinginannya tersebut.

Subjek mampu mengungkapkan tindakan yang ingin dilakukan selama ini dan dapat mengungkapkan tindakan selanjutnya untuk mengatasi masalahnya. Keinginan subjek yaitu dapat kembali berinteraksi dan mengikuti berbagai kegiatan tanpa perasaan malu terhadap dirinya dan keluarganya. Subjek mengungkapkan tindakan yang pernah dilakukan sehingga subjek mengetahui arah dan tindakan dalam pencapaian kebutuhannya. Tindakan yang Subjek lakukan adalah subjek berusaha sedikit demi sedikit untuk kembali mengikuti kegiatan dimulai dari kegiatan ibadah. Meski subjek masih merasa sulit untuk melakukannya

Sesi IV:penilaian dan tindakan (evaluation). Pada sesi ini, konselor membantu subjek untuk dapat mengevaluasi diri dari tindakan yang dilakukannya. Sebelum memulai proses konseling, konselor dan subjek akan mengevaluasi tindakan yang telah dilakukan subjek selama ini, dilanjutkan dengan membuat rencana tindakan untuk membantu subjek memenuhi keinginan dan kebutuhannya. Subjek beranggapan bahwa dengan banyaknya hutang yang dimiliki anak dan menantunya, membuat subjek dikucilkan dari lingkungan dan menjadi bahan perbincangan orang lain sehingga subjek memilih untuk tidak mengikuti berbagai kegiatan PKK dan kerohanian.

Subjek menyadari bahwa selama ini tindakan yang dilakukannya kurang tepat sehingga subjek ingin berubah untuk menjadi lebih baik. Setelah mengevaluasi tindakan yang telah subjek lakukan, dilanjutkan dengan tindakan yang akan subjek lakukan. Subjek akan berusaha untuk menerima kenyataan yang harus diterima dan dijalani, bahwa kondisi keluarga subjek saat ini mempunyai banyak hutang. Subjek berusaha untuk memahami keadaan tersebut adalah bukan suatu alasan utama untuk tidak diterima orang lain dan bukan merupakan pembatas subjek untuk bersosialisasi. Subjek berusaha untuk menjadi diri yang lebih baik dan sesuai dengan keadaan diri saat ini.

\section{Sesi V: Menyusun keinginan dan komitmen bersama} (plan). Setelah memahami dan meyakini tentang keinginan serta tindakan yang harus dilakukan maka dilanjutkan dengan membuat komitmen dari beberapa pilihan komitmen, yaitu: (1) saya tidak mau menerima kondisi yang ada pada diri saya, (2) saya akan menerima kondisi yang ada pada diri saya dan keluarga saya, (3) saya akan berusaha sebaik mungkin menerima dan selalu berpikir positif terhadap kenyataan yang ada pada diri saya, dan (4) saya akan melakukan apapun untuk dapat bersikap positif.

Berdasarkan beberapa pilihan komitmen tersebut, subjek memilih yang ketiga yaitu mengusahakan sebaik mungkin menerima dan selalu berpikir positif terhadap kenyataan yang ada pada dirinya. Setelah subjek menyadari pentingnya berpikir positif, maka subjek akan berusaha sebaik mungkin untuk bersikap positif untuk memenuhi keinginannya yaitu mengikuti kegiatan di masyarakat tanpa rasa malu dengan berusaha rutin mengikuti kegiatan di masyarakat. Sesi konseling ini diakhiri dengan posttest menggunakan skala DASS untuk mengukur tingkat stres subjek setelah melakukan seluruh rangkaian konseling.

Sesi VI: Follow Up. Dilakukan 2 minggu setelah terapi diberikan. Subjek mengatakan setelah proses terapi berakhir, subjek merasa terapi membantu subjek dalam mencapai hal-hal yang diinginkannya.

\section{Hasil dan Pembahasan}

\section{Hasil}

Berdasarkan hasil intervensi yang telah diberikan dapat diketahui bahwa konseling realitas dapat menurunkan tingkat stres subjek. Perubahan yang terjadi pada subjek menunjukkan adanya penurunan skor tingkat stres pada skala DASS yang disertai perilaku yang tampak yaitu subjek rutin mengikuti kegiatan kerohanian di gereja dan kegiatan PKK. Hasil intervensi menunjukkan adanya penurunan tingkat stres pada skala DASS, pada saat 


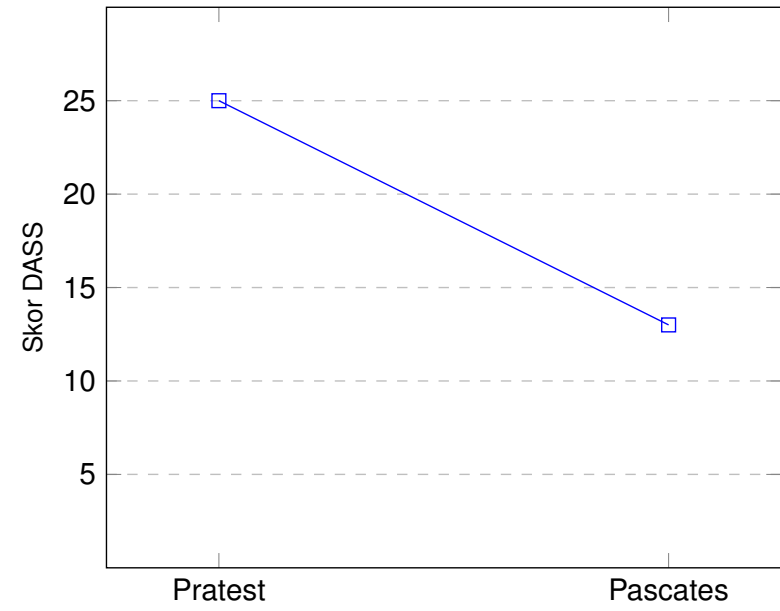

Gambar 1. Perubahan tingkat stress berdasarkan DASS sebelum dan sesudah intervensi.

sebelum intervensi pada kategori sedang dengan skor 25 dan setelah dilakukan intervensi menurun menjadi dalam kategori ringan dengan skor 13. Perubahan tingkat stres subjek pada saat pretest dan posttest dapat dilihat pada Gambar 1.

Penurunan skor tingkat stres subjek dapat dilihat dari perubahan yang terjadi pada proses konseling yang diperkuat dengan hasil wawancara subjek. Subjek memandang dirinya menjadi lebih positif. Subjek mampu melaksanakan dan memenuhi target disetiap sesi dan tahapan konseling realitas. Subjek percaya bahwa dirinya mempunyai kemampuan untuk mengatasi masalah yang dialaminya. Selain itu, subjek juga menyadari bahwa ia masih mempunyai keluarga yang memperhatikan. Subjek juga aktif melakukan kegiatan kerohanian dan tidak lagi merasa kesepian.

\section{Pembahasan}

Berdasarkan hasil intervensi menunjukkan bahwa konseling realitas dapat menurunkan tingkat stres subjek. Dalam kasus ini target perubahan tercapai dengan skor skala stres pada DASS yang mengalami penurunan. Intervensi yang diberikan pada subjek menunjukkan adanya perubahan ke arah yang lebih baik dilihat dari penurunan skor dan tingkat stres. Selain itu adanya perubahan perilaku subjek yang sudah mampu memandang dirinya secara positif dan mampu mengatasi stresnya. Sebelum intervensi dilakukan, subjek memandang dirinya sebagai seseorang yang tidak berharga sehingga subjek seringkali mengalami stres dan merasa kesepian.

Pada penelitian yang sebelumnya yang dilakukan pada lansia juga ditemukan bahwa terapi realitas dapat meningkatkan harga diri pada subjek. Konseling realitas dapat membuat seseorang memahami dirinya sendiri bahkan pada seorang lansia sekalipun (Farnoodian, 2016; Younesi et al., 2017). Teknik yang digunakan dalam konseling realitas mencoba menanyakan pada diri subjek bahwa pilihan dan strategi yang telah ia buat akan berdampak pada perilaku terhadap diri dan orang lain (Nelson-Jones, 2015). Kebutuhan yang dapat terpenuhi pada seseorang akan berdampak pada identitas diri. Apabila masalah-masalah dapat ditangani dengan baik maka akan terbentuk konsep diri yang positif.

Penerapannya konseling realitas dapat meningkatkan kemampuan penyesuaian diri seseorang terhadap stres dan kecemasan yang dirasakan. Melalui intervensi ini, subjek diajarkan untuk bertanggung jawab terhadap apa yang ia lakukan sehingga secara emosional subjek lebih dapat menyesuaikan diri ketika ada kondisi yang tidak diharapkan terjadi.

Konseling realitas melibatkan cara belajar dengan perencanaan sehingga individu akan memiliki perilaku lebih efektif. Selain itu, Glasser berpendapat bahwa nilai antara terapis dan subjek sebagai fokus keberhasilan suatu terapi (Sommers-Flanagan \& Sommers-Flanagan, 2015). Konseling realitas merupakan salah satu metode yang berdasarkan pemikiran realistis serta emosional. Teori ini berdasarkan pada perubahan perilaku ketika berhadapan pada kondisi yang tidak diinginkan. Perubahan pada individu akan berdampak pada berbagai aspek mental, psikologis, dan kepribadian seseorang (Glasser, 2003).

Terapi realitas dalam konseling membantu seseorang dalam memenuhi keinginan dan kebutuhan, dan mengevaluasi kebutuhan mereka menjadi suatu perilaku (Wubbolding, 2017). Masing-masing individu mengembangkan diri dan terlibat dengan orang lain sesuai dengan perannya untuk pembentukan identitas diri (Corey, 2013). Tujuan dari konseling realitas, membantu mencapai rasa kebebasan dan tujuan yang subjek pikirkan yang merupakan penentu keberhasilan konseling.

Konseling realitas memiliki beberapa langkah (WDEP) yang dinilai dapat membantu subjek dalam meningkatkan harga diri sehingga stres yang dirasakan dapat berkurang. Subjek mampu mengubah pikiran, perasaan, dan perilaku menjadi lebih positif sehingga dapat menjadi individu yang lebih baik dan mampu mengenali dirinya, memahami apa yang diinginkan dan lebih optimis dalam menghadapi permasalahannya (Vahidiborji et al., 2017). Konseling ini juga menekankan pada masa kini dan berfokus pada komitmen individu dalam pelaksanaannya untuk mencapai tujuan yang telah disepakati bersama (Corey, 2013).

Kekurangan dalam terapi ini terdapat pada proses asesmen kasus yaitu kurangnya informasi dari keluarga dan orang terdekat subjek. Maka, dalam terapi selanjutnya diperlukan penggalian data dari keluarga dan orang terdekat agar data yang diperoleh lebih lengkap.

\section{Simpulan}

Konseling realitas dapat menurunkan tingkat stres subjek. Perubahan yang terjadi pada Subjek menunjukkan adanya penurunan skor stres dari 25 menjadi 13 pada skala DASS dan disertai perubahan perilaku yang tampak yaitu dengan rutin mengikuti berbagai kegiatan. 


\section{Referensi}

Call, K. T., \& Mortimer, J. T. (2003). Arenas of comfort in adolescence: A study of adjustment in context. Journal of Adolescence, 26(1), 143-144. https://doi.org/10.1016/s01401971(02)00111-2

Corey, G. (2013). Theory and Practice of Counseling and Psychotherapy (Vol. 29). https://doi.org/10.2307/583738

Ellsworth, L. (2007). Choosing to heal: Using reality therapy in the treatment of sexually abused children. In Choosing to heal: Using reality therapy in the treatment of sexually abused children. Routledge/Taylor \& Francis Group.

Elsayed, F. K. (2017). The effectiveness of counseling program to improve coping strategies with perceived family violence in a sample of saudi female saudi university students mogeda elkeshky. (January 2015).

Farnoodian, P. (2016). The effectiveness of group reality therapy on mental health and self-esteem of students. International Journal of Medical Research \& Health Sciences, (9), 18-24. https://doi.org/2319-588

Galanakis, M. J., Palaiologou, A., Patsi, G., Velegraki, I.M., \& Darviri, C. (2016). A literature review on the connection between stress and self-esteem. Psychology, 07(05), 687-694. https://doi.org/10.4236/psych.2016.75071

Glasser, W. (2003). Warning: Psychiatry can be hazardous to your mental health. Destructive Trends in Mental Health: The Well Intentioned Path to Harm, 7(2), 113-128. https: //doi.org/10.4324/9780203956229-15

Hubbs, A., Doyle, E. I., Bowden, R. G., \& Doyle, R. D. (2012). Relationships among self-esteem, stress, and physical activity in college students. Psychological Reports, 110(2), 469-474. https://doi.org/10.2466/02.07.09.PR0.110. 2.469-474

Jusoh, A. J., Mahmud, Z., \& Mohd Ishak, N. (2008). The patterns of reality therapy usage among Malaysian counselors. International Journal of Reality Therapy, 28(1), 5-14.

Karimyar J. M., \& Mosallanejad, L. (2014). The impact of reality therapy on metacognition, stress and hope in addicts. Global Journal of Health Science, 6(6), 281-287. https://doi.org/10. 5539/gjhs.v6n6p281

Keyes, C. L. M., \& Haidt, J. (2016). Flourishing: Positive psychology and the life well lived. Encyclopedia of Family Studies, 20(5), 1-2. https://doi.org/10.1002/9781119085621. wbefs 442
Lazarus, R. S., \& Folkman, S. (1984). Stress, appraisal, and coping. In Springer. New York, NY: Springer New York.

Lopez, S. J. (2009). The encyclopedia of positive psychology. In Control. Wiley-Blackwell Publishing.

Nelson-Jones, R. (2015). Teori dan praktik konseling dan terapi. Yogyakarta: Pustaka Belajar.

Nematzadeh, A., \& Sary, H. S. (2014). Effectiveness of group reality therapy in increasing the teachers' happiness. Procedia - Social and Behavioral Sciences, 116, 907-912. https://doi.org/10.1016/j.sbspro.2014.01.318

Sommers-Flanagan, J., \& Sommers-Flanagan, R. (2009). Clinical interviewing (4th ed.). New Jersey: John Wiley \& Sons Inc.

Sommers-Flanagan, J., \& Sommers-Flanagan, R. (2015). Counseling and psychotherapy theories in context and practice skills, strategies, and techniques. New Jersey: John Wiley \& Sons Inc.

Tan, S. C., Yeoh, A. L., Choo, I. B., Huang, A. P., Ong, S. H., Ismail, H., ... Chan, Y. H. (2012). Burden and coping strategies experienced by caregivers of persons with schizophrenia in the community. Journal of Clinical Nursing, 21(17-18), 2410-2418. https://doi.org/10.1111/j.1365-2702. 2012.04174.x

Vahidiborji, G., Jadidi, M., \& Donyavi, R. (2017). The study of effectiveness of reality therapy on adjustment of female adolescents with anxiety. Journal of Psychology \& Clinical Psychiatry, 7(1), 1-4. https://doi.org/10.15406/jpcpy.2017. 07.00414

Wubbolding, R. E. (2017). Reality Therapy and Self-Evaluation. In Reality Therapy and Self-Evaluation. https://doi.org/10. 1002/9781119376248

Yao, Y. W., Chen, P. R., Li, C. shan R., Hare, T. A., Li, S., Zhang, J. T., ... Fang, X. Y. (2017). Combined reality therapy and mindfulness meditation decrease intertemporal decisional impulsivity in young adults with Internet gaming disorder. Computers in Human Behavior, 68, 210-216. https: //doi.org/10.1016/j.chb.2016.11.038

Younesi, S., Khazan, K., Jani, S., \& Mahdizadeh, Z. (2017). The effectiveness of reality therapy concepts on self-esteem of the elderly in the center of Aramesh in Parsabad. Journal of Advances in Medical and Pharmaceutical Sciences, 12(1), 1-8. https://doi.org/10.9734/jamps/2017/28297 